International Journal of Agriculture, Environment and Bioresearch

Vol. 06, No. 05; 2021

ISSN: $2456-8643$

\title{
EVALUATION OF CONSUMER PREFERENCE FOR THE CONSUMPTION OF PROCESSED CHICKEN: A CASE STUDY OF PUBLIC SERVANTS IN ONDO STATE, NIGERIA
}

\author{
${ }^{1 *}$ Akinbola, A.E., ${ }^{2}$ Aturamu, O.A., ${ }^{1}$ Oladoyin, O.P. and ${ }^{3}$ Oladayo, T.O. \\ ${ }^{1}$ Department of Agricultural Economics, Adekunle Ajasin University, P.M.B 001, Akungba-Akoko, Ondo State, \\ Nigeria. \\ ${ }^{2}$ Department of Agricultural Science and Technology, BamideleOlumilua University of Education, Science and \\ Technology, P.M.B 250, Ikere-Ekiti, Ekiti State, Nigeria. \\ ${ }^{3}$ Division of Agricultural Biochemistry and Nutrition, Federal University of Technology, P.M.B 704, Akure, Ondo \\ State, Nigeria
}

https://doi.org/10.35410/IJAEB.2021.5670

\begin{abstract}
The study was conducted to examine the consumer preference for consumption of processed chicken among public servants in Ondo State, Nigeria. Primary data were used for this study with the aid of a well-structured questionnaire. A multistage sampling procedure was used to randomly select 120 respondents. Descriptive statistics, Pearson correlation test and logistic regression were employed to analyze the data. The results showed that the mean age of the public servant was 39 years and about $52.5 \%$ of the workers were female. The average household size was 4 , about $62.5 \%$ of the respondents were married and the public servant had an average working experience of 5 years. The results revealed that about $53.3 \%$ of the workers had preference for processed chicken and only $5.8 \%$ of the respondent consume processed chicken daily. Also, the result showed that $26.3 \%$ of monthly budget on food was spent on consumption of processed chicken, which amounted to N11,533.33. The result of acceptance of processed chicken showed that taste was the major factor to their preference and consumption of processed chicken. Also, there is a positive relationship between income and the quantity of processed chicken consumed. The logistic results showed that level of education, price of processed chicken, quantity consumed and income level were the major factors explaining the preference for processed chicken to other meat productsin the area. The result of the study also showed that high price, income level and market difficulties were the main constraints to consumption of processed chicken by the public servant. It was then recommended that unemployed graduates should be encouraged to take advantage of the available demand for processed chicken meat among public servants and broiler meat marketers should be enlightened about the availability of demand for processed chicken meat among public servants.
\end{abstract}

Keywords: Chicken, consumers, logistic regression, public servants, preference, Nigeria.

\section{INTRODUCTION}

The Nigerian poultry sector dominated by chickens has grown rapidly over the years although its future remains uncertain. In spite of that, chicken meat consumption has continuously expanded and estimated at $\$ 80$ billion ( $\$ 600$ million) and is comprised approximately 165 million birds, which produced 290,000 MT of poultry meat in 2013. From a market size. Nigeria has the 
second largest chicken population after South Africa's 200 million birds, 2013 (FAOSTAT, 2017).Chicken importation (with the exception of day-old-chicks) was banned by Nigeria in 2003, which spurred growth in domestic poultry production. Statistics from Eurostat, however, highlights that between 2009 and 2011 over 3 million MT worth of poultry products were imported into the Republic of Benin, with the preponderance of these products ending up in the Nigerian market. If this is reflected in overall assumptions, estimated poultry meat consumption in Nigeria is approximately 1.2 million MT. The Nigerian poultry sector is extremely fragmented with most of the chicken raised in 'backyards' or on poultry farms with less than 1,000 birds. However, there are a number of large commercial players in the sector most of whom are located in south-western Nigeria, in close proximity to Lagos and its large market of 17.5 million people. The preference and consumption of chicken meat can be considered as a universal phenomenon and chicken meat is greatly accepted by consumers worldwide as compared to the other meat consumption. According to Borchert (1998), chicken meat is one of the most consumed food worldwide amongst the urban and rural residents. The increase of chicken meat consumption is due to the versatility of the meat, relatively low cost in comparison to other meat, the acceptance of the chicken meat to all religions and increase in the household income. Nestle (1999) indicated that meat consumption is viewed as a reflection of favorable economic conditions.

The growth in consumption especially for processed chicken is to some extent, attributed to its perception as a healthy alternative to red meats besides the low retail prices and ease of preparation. The overall growth in demand for poultry meat would be much accelerated by the surge in human population, rise in incomes, and urbanization. This implies that the rural poor and landless in the developing countries are bound to benefit from the expanded livestock markets and improved household food security, thus alleviating the prevalent protein and micronutrient deficiencies (Nestle, 1999).

Preferential consumption exists in spite of chicken being an important source of animal protein However, it worth being noted that consumption and preferences of processed chicken like other food products is not evenly distributed in Nigeria, according to Dauda et al. (2013). Factors such as consciousness of consumers on the nutritional and health value of chicken meat (Rankin, 2000); income level of households: the prices of meats substitute for chicken meat (Oliphant, 1997), population growth increases the absence of religious obstacles (Oliphant, 1997) and tastiness may be effective on the increase of chicken consumption.

Again, it has been observed by Adejobi et al. (2010) that increase in population growth accompanied by urbanization and increasing affluence is likely to increase the demand for high quality animal protein. Consumer preferences research, which is the scientific study of the processes consumers use to select, secure and consume products that satisfy their needs. Knowledge of consumer preferences directly affects marketing strategy. This is because of the marketing concept. The idea that processed chicken producers exist to satisfy customer needs (Winer, 2000). The producers can satisfy those needs only to the extent that they understand their customers. For this reason, marketing strategies must incorporate knowledge of consumer preferences into every facet of a strategic marketing plan (Solomon, 2002). There is a widespread recognition that consumer preferences are the key to contemporary marketing success. In order to understand the consumers' buying preference for processed chicken among Civil Servants in Ondo State, it is necessary to know the factors which influence the consumer preference and prioritize the factors. Hence, there is a genuine need to understand the factors 
influencing the preferences of consumers when they shop for processed chicken. Therefore, it is against this background that the study assessed the consumer preference for consumption of processed chicken among public servants in Ondo State, Nigeria. The specific objectives are to examine the Socioeconomic Characteristics of consumers in the study area;describe the level of acceptability of processed chicken in the area;compute the proportion of household food budget taken by processed chicken in the area;determine the factor influencing the preference for processed chicken in the area; andidentify the constraints faced by respondents in consuming processed chicken in the area.

Methodology

The Study was carried out in Ondo State, Nigeria. The State has 18 Local Government Areas with its headquarters in Akure as shown in Figure 1. It is located on longitude $4^{0} 30^{1}$ and $6^{0} 00^{1} \mathrm{E}$ and latitude $4^{0} 45^{1}$ and $8^{0} 15^{1}$ North. The State has abundant land estimated to be $13.595 \mathrm{~km}^{2}$.

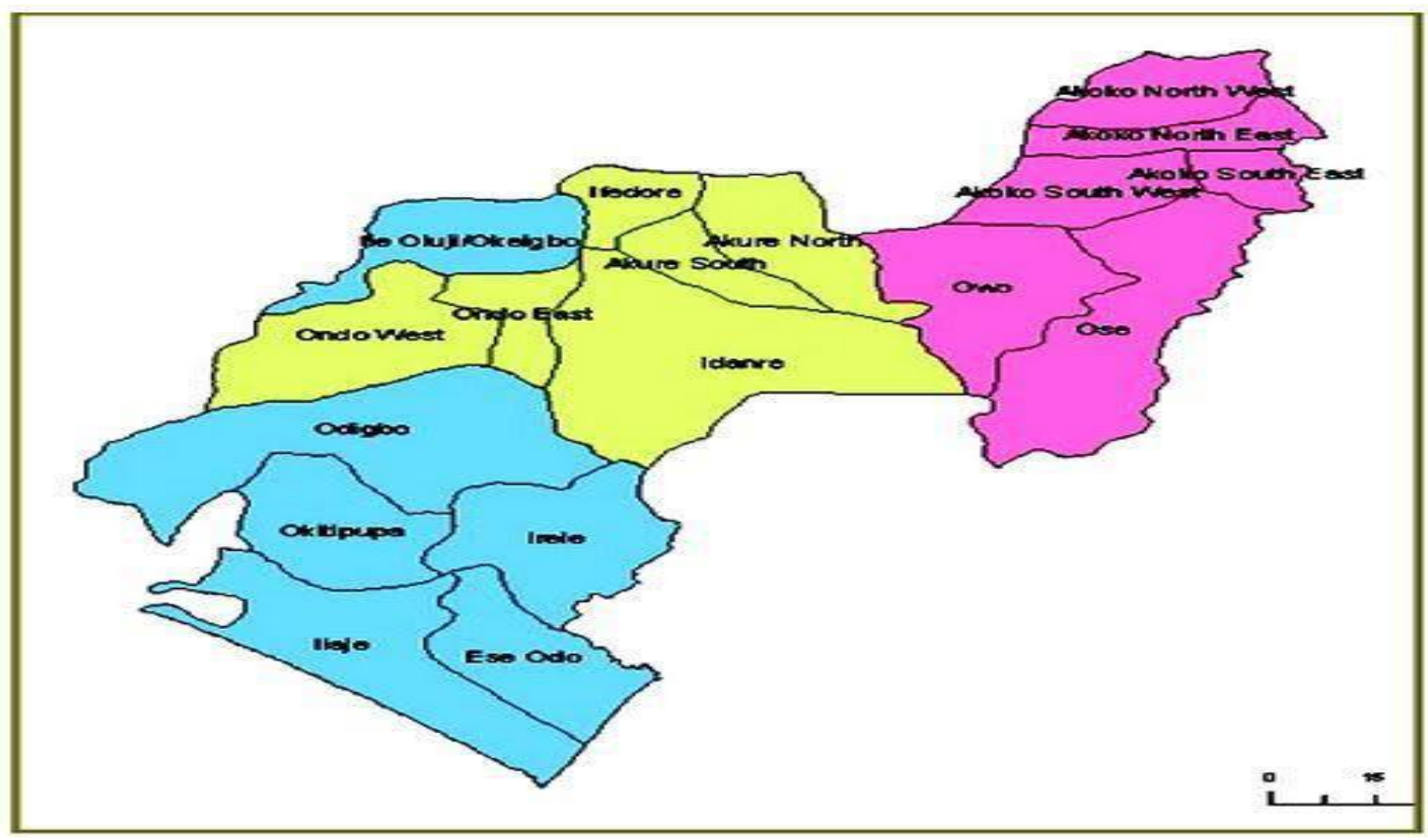

Figure 1: Map of Ondo State

Source: Wikipedia.org

The data for the study were collected from a primary source with the aid of questionnaire and interview schedule. A two-stage sampling procedure was employed in selecting the respondents from the major state-owned institutions and government ministries in the State. Stage one involved the use of purposive sampling in selecting two (2) State owned institutions and two (2) government ministries in the area.Stage two involved a snow balling sampling procedure to select 60 workers from the State owed institutions and 60 workers from government ministries, therefore, formed a total number of 120 public servants which were used for the study.Descriptive statistics, logit regression model and correlation test were used for the objectives as the analytical techniques for this study.

Model Specification: The study employed the logit regression analysis to determine the significance of the number of factors which contribute to the consumer's preference for 
processed chicken as also used in similar dichotomous studies (Igbalajobi et al., 2013; Ehinmowo et al., 2017; Olutumise et al., 2021). The explicit function of the model was:

$\mathrm{Y}=\boldsymbol{\beta}_{0}+\boldsymbol{\beta}_{1} \mathrm{x}_{1}+\boldsymbol{\beta}_{2} \mathrm{x}_{2}+\boldsymbol{\beta}_{3} \mathrm{x}_{3}+\boldsymbol{\beta}_{4} \mathrm{x}_{4}+\boldsymbol{\beta}_{5} \mathrm{x}_{5}+\boldsymbol{\beta}_{6} \mathrm{x}_{6}+\boldsymbol{\beta}_{7} \mathrm{x}_{7}+\varepsilon_{i}$

Where;

$\mathrm{Y}=$ preference for chicken (1- preferred, 0 - otherwise)

$\boldsymbol{\beta}_{0}=$ Constant,

$\mathrm{X}_{1}=$ income (\#),

$\mathrm{X}_{2}=$ Marital status (1- married, 0 - otherwise)

$\mathrm{X}_{3}=$ Household's size, (numbers)

$\mathrm{X}_{4}=$ Price of Chicken products (\#)

$\mathrm{X}_{5}=$ Quality of the products (rating scale),

$\mathrm{X}_{6}=\mathrm{sex}$ (1- male, 0 - otherwise)

$\mathrm{X}_{7}=$ Age of the respondent (years)

$\varepsilon=$ The error term.

\section{RESULTS AND DISCUSSION}

\section{Socio-economic Characteristics of the Respondents}

The result in Table 1 showed that the sampled respondents for the study were largely female headed households with 52.5\%. Gender of household head could influence food consumption pattern of households and this was reported by Agboola (2003) that gender was one of the socioeconomic characteristics that was significant in influencing household demand. The average age of 39.2years old was recorded. Household head could influence household consumption as indicated by Omonona et al. (2010), who revealed that age was a significant factor in influencing demand for chicken, palm oil, ponmo, yam flour and green leaves in their study on household food demand in semi-urban and rural households in south-west Nigeria. The Table also showed that about 56.7\% had between 1 and 3 persons per house, with the average household size of 4 members. Ogwumike, (2002) and Amazaet al. (2009) reported that the number of persons living in a household is in close relation with consumption. Emphasizing that the total expenditure and household size are positively and directly related. The study clearly showed that majority $(62.5 \%)$ of the respondents were married meaning that the decision on consumption pattern is highly influenced by couples. Result of the analysis corroborates with the findings of Akinola (2007), Ebitigha (2008) and Oludipe (2009) who stated that majority of work forces were married. Marriage can change people's diet significantly due to preferences, increase in purchasing power and relocation or urbanization.The results also revealed that all the respondents had attained and obtained at least one form of formal education or the other. This will allow them to make a rational choice and decision on expenditure on food items consumed.The result showed that majority (53.3\%) of the respondent earned income of at most $\$ 100,000$, with an average of N85,500.00. The findings prove that majority of the interviewed respondents are low-income earners. The high variability of household income implies a wider variation in purchasing power of households and subsequently, the households demand for food (Onyemauwaet al., 2008; Okidim, 2012) and the household income influences food consumption. 
Table 1: Socioeconomic Characteristics of the Respondents

\begin{tabular}{|llll|}
\hline Variables & Frequency & Percentage & Mean \\
\hline Sex & & & \\
Male & 57 & 47.5 & \\
Female & 63 & 52.5 & \\
\hline Age(years) & & & \\
$<30$ & 27 & 22.5 & 39.2 \\
$31-40$ & 47 & 39.2 & \\
$41-50$ & 28 & 23.3 & \\
$>51$ & 18 & 15.0 & \\
\hline Marital status & & & \\
Single & 38 & 31.7 & \\
Married & 75 & 62.5 & \\
Divorced & 4 & 3.3 & \\
Widow & 3 & 2.5 & \\
\hline Educational Status & & & \\
Primary/Secondary Education & 8 & 6.7 & \\
Postsecondary Education & 103 & 85.8 & \\
Postgraduate & 9 & 7.5 & \\
\hline Household size & & & \\
$<3$ & 68 & 56.7 & \\
$4-6$ & 39 & 32.4 & \\
$7-10$ & 8 & 6.7 & \\
$>15$ & 5 & 4.2 & \\
\hline Income & & & \\
$<100000$ & 64 & 53.3 & \\
100,001-200,000 & 44 & 7.5 & \\
200,001-300000 & 9 & 2.5 & \\
$>300,000$ & 3 & 100.0 & \\
\hline Total & 120 & & \\
\hline Soure: Fil Surey, & & & \\
\hline
\end{tabular}

Source: Field Survey, 2021

\section{Preference and Frequency of Consumption}

The result revealed that $53.3 \%$ of the respondents preferred processed chicken to other meat type while $46.7 \%$ do not. $5.8 \%$ of them consume processed chicken every day, $26.7 \%$ consume it at least once a week. The findings also revealed that $33.3 \%$ consumes processed chicken once in every two weeks and $34.2 \%$ consumes it occasionally presented as reported in the Table 2 .

Table 2: Distribution of Respondent by Preference and Consumption of Processed Chicken

\begin{tabular}{|lll|}
\hline Preference & Frequency & Percentage \\
\hline Yes & 64 & 53.3 \\
No & 56 & 46.7 \\
\hline Frequency of consumption & &
\end{tabular}


Vol. 06, No. 05; 2021

ISSN: $2456-8643$

\begin{tabular}{|lll|} 
Everyday & 7 & 5.8 \\
once a week & 32 & 26.7 \\
every two weeks & 40 & 33.3 \\
Occasionally & 41 & 34.2 \\
\hline Total & 120 & 100.0 \\
\hline
\end{tabular}

Source: Field Survey, 2021

Processed Chicken Budget Share

The results in the Table 3 indicated that average monthly budgetsfor processed chicken was N11,533.33 while the monthly budget on Food was N43,883.333. The result revealed that the percentage of the monthly budget of food on processed chicken is $26.3 \%$ of the monthly household food budget share.

Table 3: Monthly Distribution Share of Processed Chicken on Food Budget Share

\begin{tabular}{|l|l|l|}
\hline $\begin{array}{l}\text { Average monthly budget on } \\
\text { processed chicken (\#) }\end{array}$ & $\begin{array}{l}\text { Average Monthly budget on } \\
\text { food ( } \mathbb{N})\end{array}$ & $\begin{array}{l}\text { Percentage of the monthly } \\
\text { budget on processed chicken } \\
\text { and food. }\end{array}$ \\
\hline 11533.33 & 43883.333 & 26.3 \\
\hline
\end{tabular}

Source: Field Survey, 2021

\section{Acceptance of Processed Chicken among the Respondents}

The result from the Table 4 showed that the taste of processed chicken was the major reason why public servants (respondents) consumes processed chicken $(\bar{x}=4.34)$ in the study area, followed by palatability of processed chicken which was accepted by $57.5 \%$ of the respondent. High nutrient /health benefit of processed chicken was ranked the third by $(\bar{x}=3.9)$ and price of processed chicken was the least accepted $(\bar{x}=3.53)$. Price determine the ability of individuals' buying power. Majority of respondent agree that they rejected processed chicken meat because it is expensive

Table 4: Distribution of Respondents by Acceptance of Processed Chicken

\begin{tabular}{|c|c|c|c|c|c|c|c|c|c|c|c|c|}
\hline \multirow[t]{2}{*}{$\begin{array}{l}\text { Level of } \\
\text { Acceptance }\end{array}$} & \multicolumn{2}{|c|}{ Unacceptable } & \multicolumn{2}{|c|}{$\begin{array}{l}\text { Slightly } \\
\text { acceptable }\end{array}$} & \multicolumn{2}{|c|}{ Neutral } & \multicolumn{2}{|c|}{$\begin{array}{l}\text { Slightly } \\
\text { acceptable }\end{array}$} & \multicolumn{2}{|c|}{ Acceptable } & \multirow[t]{2}{*}{ Mean } & \multirow[t]{2}{*}{ Rank } \\
\hline & $\mathrm{F}$ & $\%$ & $\mathrm{~F}$ & $\%$ & $\mathrm{~F}$ & $\%$ & $\mathrm{~F}$ & $\%$ & $\mathrm{~F}$ & $\%$ & & \\
\hline $\begin{array}{ll}\text { Taste } & \text { of } \\
\text { processed } & \\
\text { chicken }\end{array}$ & 4 & 3.3 & 11 & 9.2 & 12 & 10 & 6 & 5 & 87 & 72.5 & 4.34 & $1^{\mathrm{st}}$ \\
\hline $\begin{array}{l}\text { Mouth texture } \\
\text { and palatability } \\
\text { of processed } \\
\text { chicken }\end{array}$ & 16 & 13.3 & 8 & 6.7 & 16 & 13.3 & 11 & 9.2 & 69 & 57.5 & 3.91 & $2^{\text {nd }}$ \\
\hline $\begin{array}{l}\text { High } \\
\text { Nutrient/health } \\
\text { benefit of } \\
\text { processed } \\
\text { chicken }\end{array}$ & 8 & 6.7 & 7 & 5.8 & 28 & 23.3 & 23 & 19.2 & 54 & 45 & 3.9 & $3^{\text {rd }}$ \\
\hline
\end{tabular}


Vol. 06, No. 05; 2021

ISSN: $2456-8643$

\begin{tabular}{|llllllllllllll|}
$\begin{array}{l}\text { Appearance } \\
\text { processed } \\
\text { chicken }\end{array}$ & 14 & 11.7 & 5 & 4.2 & 37 & 30.8 & 21 & 17.5 & 43 & 35.8 & 3.62 & $4^{\text {th }}$ \\
$\begin{array}{l}\text { Affordable } \\
\begin{array}{l}\text { Price } \\
\text { processed } \\
\text { chicken }\end{array}\end{array}$ & of & 12 & 10 & 20 & 16.7 & 27 & 22.5 & 15 & 12.5 & 46 & 38.3 & 3.53 & $5^{\text {th }}$ \\
\hline
\end{tabular}

Source: Field Survey, 2021

Relationship Between Income and Quantity of Processed Chicken Consumed.

The result of the Pearson correlation in Table 5 revealed that there is a significant relationship between income and the quantity of processed chicken consumed among the public servant in the study area. The result showed that increase in respondent income will bring an increase in the quantity of processed chicken consume by the respondents. This implies that an increase in income will bring about $41.5 \%$ increase in the quantity of processed chicken consume by the respondents. The result is in line with the result of Ezemenarl et al. (2010) who noted that as family income increases, there is a corresponding increase in consumption rate.

\section{Table 5: Relationship Between Family Income and Quantity of Processed Chicken} Cosnumed

\begin{tabular}{|llll|}
\hline & & Income & Quantity consumed \\
\hline Income & Pearson correlation & 1 & $0.415^{* *}$ \\
& Sig. (2-tailed) & & 0.002 \\
& $\mathrm{~N}$ & 120 & 120 \\
\hline Quantity consumed & Pearson correlation & $0.415^{* *}$ & 1 \\
& Sig. (2-tailed) & 0.002 & \\
& $\mathrm{~N}$ & 120 & 120 \\
\hline
\end{tabular}

Source: Field Survey, 2021

**. Correlation is significant at the 0.01 level (2-tailed).

Factors Influencing Preference for Processed Chicken in the Area

The results from the consumer's preference for processed chicken in Table 6 showed that the coefficient of determination of $35.5 \%$, which implies that the independent variables accounted for about $36 \%$ in predicting preference for processed chicken in the model. Education, price of processed chicken, quantity consumed and income were the factors that statistically and significantly affect the preference for processed chicken in the study area.

Education was statistically significant at 5\% with a positive effect on choice to prefer processed chicken. This implied that an increase in respondent education level will increase the probability to prefer processed chicken by 1.04 coefficient. Price of processed chicken was also significant at $5 \%$ with a negative effect on choice to prefer processed chicken to other meat products, implying that a naira increase in the price of processed chicken, will increase the probability to consume other meat product to processed chicken by the coefficient of 4.96 .

Quantity consumed had a positive effect on choice to prefer processed chicken and was significant at $1 \%$, implying an increase in quantity consumed will increase the probability to 
prefer consume processed chicken by 2.29 coefficient. Income was also significant at $1 \%$, implying a naira increase in respondent income will increase the probability to prefer processed chicken to any other meat product by 6.23 coefficient. This result was confirmed by Laswai et al. (2005) and Silayo et al. (2004) who found out that increased in quantity consumed were mostly preferred by people.

Table 6: Binary Logistic Regression Showing the Factors Influencing Consumer's Preference

\begin{tabular}{|llll|}
\hline Variables & Coefficients & S.E. & Sig. \\
\hline Gender & -0.366 & 0.864 & 0.672 \\
Age of respondents & 0.026 & 0.033 & 0.430 \\
Marital status & -0.436 & 0.715 & 0.542 \\
Household size & -0.135 & 0.137 & 0.324 \\
Level of Education & 1.040 & 0.528 & $0.049^{* *}$ \\
Price of processed chicken & -0.496 & 0.500 & $0.047^{* *}$ \\
Quantity consumed & 2.295 & 0.837 & $0.006^{* * *}$ \\
Income level & 6.352 & 0.001 & $0.001^{* * *}$ \\
Household size & 0.268 & 0.980 & 0.785 \\
Constant & -0.254 & 1.205 & 0.445 \\
\hline
\end{tabular}

Cox \& Snell R Square $\quad 0.355$

**

***

Significant at 5 percent

Significant at 1 percent

Dependent variable: Preference for processed chicken (1- preferred, 0- otherwise)

\section{Constraints to the Consumption of Processed Chicken in the Area}

The result in Table 7 showed that high price of processed chicken was the major challenge faced by the respondents to consumption of processed chicken $(\bar{x}=2.57)$. in the study area, this was attributed to the cost incurred on production of broiler, followed by income level which was ranked the second constraint by $(\bar{x}=2.57)$. difficult access to processed chicken market was ranked the third constraint by the respondent in the study area, about $46.7 \%$ of them agreed it was a constraint for them in preferring and consuming processed chicken. Household size, taste and palatability, age constraint was ranked the $4^{\text {th }}, 5^{\text {th }}$ and $6^{\text {th }}$ by $(\bar{x}=2.11),(\bar{x}=2.0)$ and $(\bar{x}=$ 1.91) respectively. A small household size will consume more of processed chicken compare to a larger household size, personal negative attitude was agreed to be a constraint by $1.9 \%$ of the respondent, norms and culture, and religion were the least constraint by $(\bar{x}=1.72)$ and $(\bar{x}=1.29)$ respectively.

Table 7: Distribution by The Constraint Faced to Consumption of Processed Chicken

\begin{tabular}{|c|c|c|c|c|c|c|c|c|c|c|}
\hline \multirow[t]{2}{*}{ Constraint } & \multicolumn{2}{|c|}{$\begin{array}{l}\text { Not a } \\
\text { constraint }\end{array}$} & \multicolumn{2}{|c|}{$\begin{array}{l}\text { Mild } \\
\text { constraint }\end{array}$} & \multicolumn{2}{|c|}{ Constraint } & \multicolumn{2}{|c|}{$\begin{array}{l}\text { Serious } \\
\text { constraint }\end{array}$} & \multirow[t]{2}{*}{ Mean } & \multirow[t]{2}{*}{ Rank } \\
\hline & $\mathrm{F}$ & $\%$ & $\mathrm{~F}$ & $\%$ & $\mathrm{~F}$ & $\%$ & $\mathrm{~F}$ & $\%$ & & \\
\hline $\begin{array}{l}\text { High price of processed } \\
\text { chicken }\end{array}$ & 30 & 25 & 35 & 29.2 & 12 & 10 & 43 & 35.8 & 2.57 & $1 \mathrm{st}$ \\
\hline Amount of my income & 26 & 21.7 & 43 & 35.8 & 16 & 13.3 & 35 & 29.2 & 2.5 & 2nd \\
\hline
\end{tabular}


Vol. 06, No. 05; 2021

ISSN: $2456-8643$

\begin{tabular}{|c|c|c|c|c|c|c|c|c|c|c|}
\hline $\begin{array}{l}\text { Difficult accessibility to } \\
\text { market where I can purchase } \\
\text { processed chicken }\end{array}$ & 30 & 25 & 34 & 28.3 & 48 & 40 & 8 & 6.7 & 2.28 & $3 \mathrm{rd}$ \\
\hline Number of my household & 48 & 40 & 35 & 29.2 & 13 & 10.8 & 24 & 20 & 2.11 & 4th \\
\hline $\begin{array}{l}\text { The taste and palatability of } \\
\text { processed chicken }\end{array}$ & 52 & 43.3 & 25 & 20.8 & 34 & 28.3 & 9 & 7.5 & 2 & 5 th \\
\hline $\begin{array}{l}\text { Consuming processed } \\
\text { chicken is not advice for my } \\
\text { age group }\end{array}$ & 66 & 55 & 18 & 15 & 17 & 14.2 & 19 & 15.8 & 1.91 & 6th \\
\hline $\begin{array}{l}\text { Personal negative attitude } \\
\text { towards processed chicken }\end{array}$ & 51 & 42.5 & 39 & 32.5 & 21 & 17.5 & 9 & 7.5 & 1.9 & 7 th \\
\hline $\begin{array}{l}\text { Norms and culture of my } \\
\text { society }\end{array}$ & 64 & 53.3 & 32 & 26.7 & 18 & 15 & 6 & 5 & 1.72 & 8th \\
\hline $\begin{array}{l}\text { My religion is totally against } \\
\text { consuming processed } \\
\text { chicken }\end{array}$ & 101 & 84.2 & 10 & 8.3 & 2 & 1.7 & 7 & 5.8 & 1.29 & 9th \\
\hline
\end{tabular}

Source: Field Survey, 2021

\section{CONCLUSION AND RECOMMENDATIONS}

The workers income had a significant positive effect on the quantity of processed chicken consumed, i.e., increase in respondent income will increase the quantity of processed chicken consumed. This study also revealed that $26.3 \%$ of the household monthly budget share was on processed chicken and taste of processed chicken was the major factor considered to preferring and consumption of processed chicken.Finally, this study has also revealed that the level of education, price of processed chicken, quantity consumed and income were significantly related to their choice of preferring and consuming processed chicken in the area. Based on the findings of this study, it is therefore recommended that unemployed graduates should be encouraged to take advantage of the available demand for processed chicken meat among public servants. The broiler meat marketers should be enlightened about the availability of demand for processed chicken meat among public servants. Processed chicken marketers should target higher income among educated consumers in neighborhoods/markets in order to boost the net income accrue from the enterprise. At the same time, in order to increase the consumption of processed chicken, farmer's input resources should be subsidized to produce broiler birds at a cheaper rate so that the preference of the low-income earners could be catered for.

\section{REFERENCES}

Adejobi A. O. (2010). Food production and demand in Kebbi State Nigeria, Unpublished Ph.D thesis Department Of Agricultural Economics, University Of Ibadan, Ibadan.

Agbola, F.W. (2003).Estimation of Food Demand Patterns in South Africa Based on a Survey of Households. Journal of Agricultural and Applied Economics, 35(3): 663 - 670.

Akinola, S.R. (2007). Coping with infrastructural deprivation through collective action among rural people in Nigeria.Nordic Journal of African Studies, 16(1), 30-46. 
Amaza, P., Abdoulaye, T., Kwaghe, P., andTegbaru, A. (2009).Changes in household food security and poverty status in PROSAB area of Southern Borno State.Nigeria, IITA, Ibadan, Nigeria.

Borchert, L. L. (1998). Poultry meat quality - its impact on processed meat products. Pages 8991 in Proc. 47th Ann. National Breeders Roundtable. St. Louis, Missouri.

Ebitigha, O.(2008). Effects of Livelihood Diversification on Rural Households Socio-economic Status in Osun State, Nigeria. M.Sc. Thesis, Unpublished. Ibadan: University of Ibadan.

Ehinmowo, O.O., Fatuase, A.I. and Ojo, S.O. (2017). Empirical Analysis of Poverty Status of Small-Scale Cassava Processors in Nigeria. Journal of Agricultural Faculty of Gaziosmanpasa University, 34 (1): 26-32.

FAO (2017).Food and Agriculture Organization.Http://Faostat.Fao.Org/Site/339/Default.Aspx. Accessed 14 May 2021].

FAOSTAT (2017).Faostat: Food and Agriculture Data. Rome: FAOSTAT. (Accessed Oct 04, 2021).

Igbalajobi, O., Fatuase, A.I.and Ajibefun, I. (2013). Determinants of Poverty Incidence among Rural Farmers in Ondo State, Nigeria. American Journal of Rural Development 2 1(5): 131137.

Laswai, H.S., Silayo, V.C.K., Mpagalile, J.J., Ballegu, W.R. and John, J. (2005). Improvement and popularization of diversifiedcassava products for income generation and food Security: A case study of Kibabu. African Journal of Food, Agriculture andNutrition Development (AJFAND) 6(1): $1-15$.

Nestle, M. (1999). Meat of wheat for the next millennium, Proceedings of the Nutrition Society, Vol. 58, pp. 211-18.

Ogwumike F.O. (2002). 'An appraisal of Poverty Reduction Strategies in Nigeria' htt://www.cenbank.org/OUT/PUBLICATIONS/EFR/RD/2002

Okidim, I.A. (2012). Analysis of the Demand for and Supply of Rice in Some Selected Local Government Areas of Niger State of Nigeria.Advances in Agriculture, Sciences and Engineering Research, 2(1): $67-71$.

Oliphant, G.G. (1997). Meat and meat products.Pages 1-46 in Food Industries Manual. 24th ed. M. D. Ranken, Kill, R. C., and C. G. J. Baker, eds. Chapman and Hall, London, UK.

Oludipe, B.(2009). Livelihood Activities of Artisanal Fisher Folks in Epe Local Government Area of Lagos State, Nigeria. M.Sc. Thesis, Unpublished. Ibadan: University of Ibadan.

Olutumise, A.I.,Ajibefun, I.A., Omonijo, A.G. (2021). Effect of Climate Variability on Healthcare Expenditure of Food Crop Farmers in Southwest, Nigeria.International Journal of Biometeorology, doi:10.1007/s00484-021-02079-z. Epub ahead of print. PMID: 33474613.

Omonona, B.T., Nkang, N. M. and Ajao, F. A. (2009). Household Food Demand Analysis: A Survey of Semi-Urban and Rural Households in South-West Nigeria. Global Journal of Pure and Applied Sciences, 15(4): 315 - 324.

Onyemauwa, C.S., Odii, C.A., Lemchi, J.I., Eze, C.C., Ibekwe, U.C., and Emenyonu, C.A. (2008). Analysis of Household Consumption of Cereals in Owerri Municipality, Imo State, Nigeria.International Journal of Agricultural Research, 3(4): 273 - 280. 
Silayo, V.C.K., Mpagalile, J.J., Ballegu, W.R.W., Mtunda, K., Chilosa, D., Nyborg, I. and Makungu, P.J. (2004).Processingand utilization of cassava. Swahili monograph. TARPIISUA project. 33pp.

Solomon, J., 2002. Effects of food-safety perceptions on food demand and global trade. In: Regmi, A. (Ed.), Changing Structure of Global Food Consumption and Trade. Agriculture and Trade Report WRS-01-1. Economic Research Service, US Dept. ofAgriculture, Washington, pp. 55-66. 